\title{
$\mathrm{A}_{3}$ 食 道 癌 の 検 討
}

$\begin{array}{rrrr}\text { *植松 } & \text { 貞夫, 磯野 } & \text { 可一, 竜 } & \text { 崇正 } \\ \text { 渡辺 } & \text { 義二, 古川 } & \text { 隆男, 石川 } & \text { 達雄 } \\ \text { 今園 } & \text { 修, 菊地 } & \text { 俊之, 佐藤 } & \text { 博 }\end{array}$

\section{Clinical Study on A3 Esophageal Cancer}

\author{
Sadao Uematsu, M.D., Kaichi Isono, M.D., Munemasa Ryu, M.D., \\ Yoshiji Watanabe, M.D., Takao Furukawa, M.D., Tatsuo Ishikawa, M.D., \\ Osamu Imasono, M.D., Toshiyuki Kikuchi, M.D. and Hiroshi Sato, M.D. \\ The Second Department of Surgery, School of Medicine, Chiba University, Chiba
}

\begin{abstract}
In this paper, clinical investigations of $\mathrm{A}_{3}$ esophageal cancer are discussed with regard to the radiological findings, surgical findings, effects of the preoperative combined chemo-and radiotherapy and prognosis.

Radiological findings of the $A_{3}$ esophageal cancer were recognized by irregularity, roughness, penetration and perforation of the esophageal wall, stenosis, bending and elevation of the esophagus at and around the lesions. Surgical exploration proved that $A_{3}$ esophageal cancer invaded into the neighboring organs such as aorta, lung, trachea, diaphragm and pericardium. Among them the aorta was most frequently involved. The effects of preoperative combined therapy on the $A_{3}$ esophageal cancer could not be expected. The prognosis of the $A_{3}$ esophageal cancer was not good compared with $\mathrm{A}_{0-2}$ cancer. In order to improve the prognosis, preoperative and postoperative combined chemo-and "radiotherapy and complete resection of esophageal lesions with invaded neighboring structures should be performed.
\end{abstract}

\section{はじめに}

食道癌のX線学的所見は各症例ごとにいろい ろの所見を呈するといっても過言ではない。図 1 に示す食道癌のX線フィルムは誰がみてもそ の深達度の度合も非常に強度であることが予想 されるであろう。実際この症例は手術時大動脈 と左肺への癌浸潤が確認された切除例である。 このように食道癌の手術をおこなってみると癌 腫の外膜への浸潤の程度はその症例によりこと なるものである。すなわち癌組織が食道外膜に まったくでていないものから，あきらかに外膜

*千葉大学医学部第二外科学教室
にまで浸潤しているものや，さらに癌組織の浸 潤が他臟器におよぶようなものまで認められ, その浸潤度はじつにさまざまである。食道癌の 外膜への浸潤の程度はリンパ節転移の程度とと もに食道癌の予後を左右する大きな因子である ことは周知のところである。食道癌取り扱い規 約によれば $\mathrm{A}_{3}$ 食道癌とは癌組織の浸潤が心囊 膜, 大動脈, 大静脈, 気管, 肺などの食道の周 囲藏器に及んでいるものと定義されている。そ してこの $\mathrm{A}_{3}$ 食道癌はたとえ切除できてもその 予後は, $\mathrm{A}_{0}, \mathrm{~A}_{1}, \mathrm{~A}_{2}$ 食道癌と比較すると非常 に悪く, $\mathrm{A}_{3}$ 食道癌の治療は今後さらに検討さ れなければならないであろら。それではどのよ 


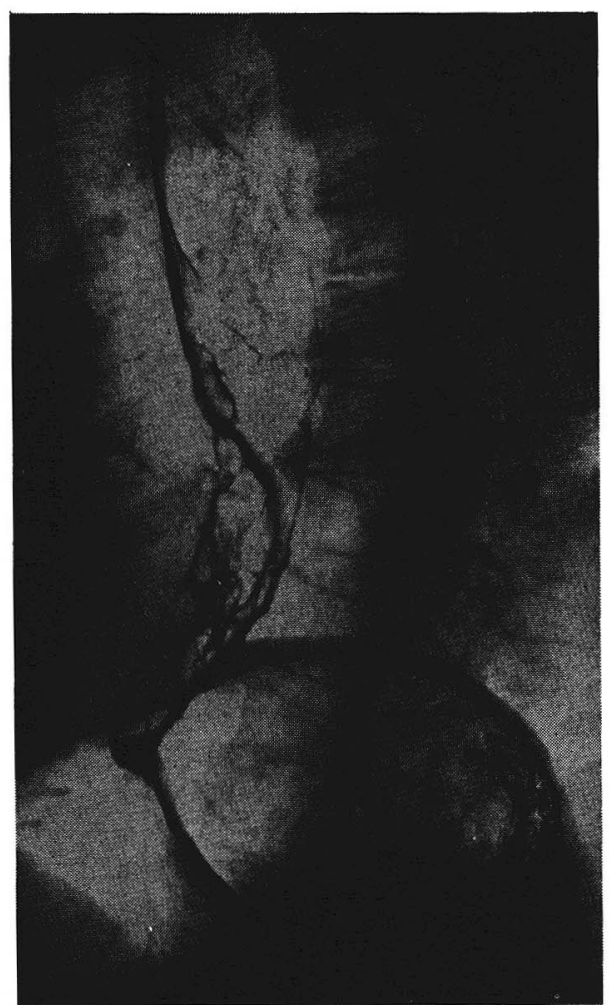

図1 $\mathrm{A}_{3}$ 食道癌症例

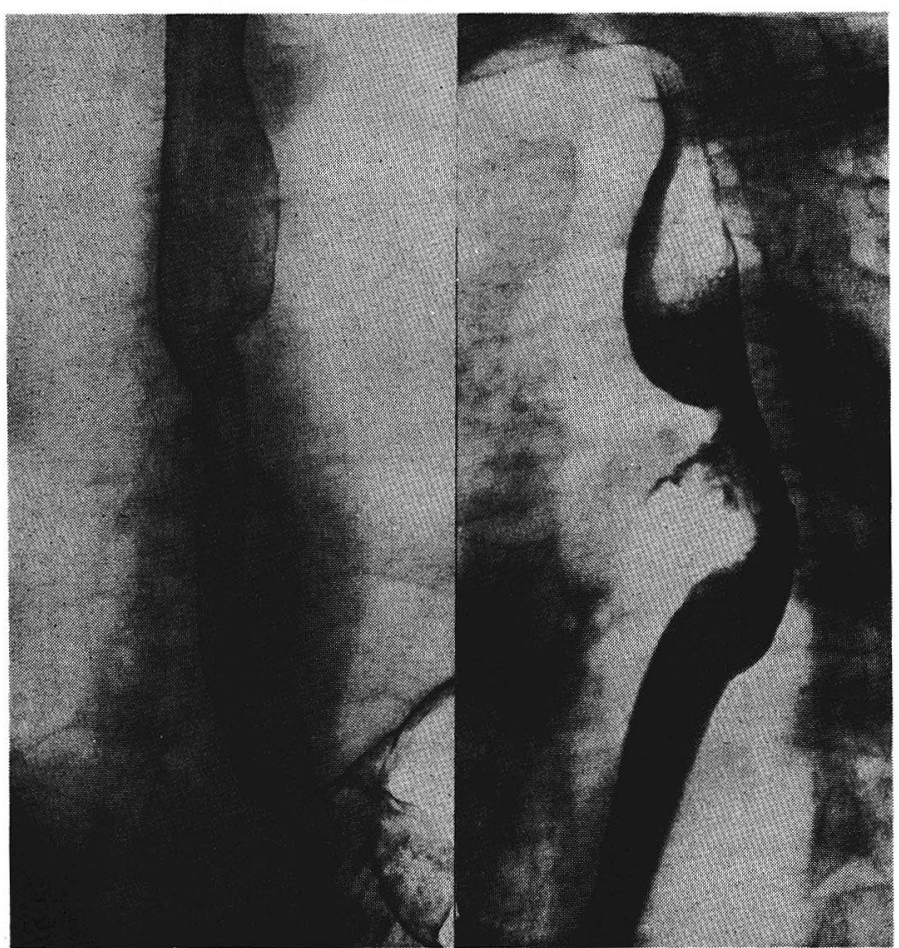

図 2 a 穿通像
らなX線学的所見を呈すれば $\mathrm{A}_{3}$ 食道癌である と推定できるかという問題が当然おこってくる であろら。 $\mathrm{A}_{3}$ 食道癌のX線学的所見を精細に 検討して手術前に $\mathrm{A}_{3}$ 食道癌を推定することは 臨床上非常に有意義なことであるので, $\mathrm{A}_{3}$ 食 道癌についてのX線学的所見を中心にその臨床 像を検討した。

\section{検索方法および検索対象}

前述のように $\mathrm{A}_{3}$ 食道癌のX線学的所見を熟 知しておくことは治療方針の決定とか予後など の推定というような臨床上の大切な問題に関し て是非とも必要であるため, $\mathrm{A}_{3}$ 食道癌につい $\tau, \mathrm{X}$ 線学的特徵, 占居部位, 壁在性, 長さ, $\mathrm{X}$ 線型, 術前合併燎法の X線学的効果, 浸潤藏 器, 予後などについて $\mathrm{A}_{3}$ 食道癌以外の食道癌 と比較検討した。検索対象は1965年より1978年 8 月までに千葉大学第 2 外科で切除した食道癌 282 例であり，このなかには $\mathrm{A}_{3}$ 食道癌が予想 された87例がふくまれている。

\section{検 索結 果}

$\mathrm{A}_{3}$ 食道癌と予想された 87 例に ついてのX線学的所見を検討する と正常の食道壁がまったく消失し てしまって食道壁の強度の壁不整 像, 狭窄, 穿通, 穿孔, 屈曲, 膨隆, 凹凸像などの非常にきびしい所見 が単独にあるいは重複して認めら れている(表 1 , 図 $2 \mathrm{a} b \mathrm{~cd}$ )。 $\mathrm{A}_{3}$ 食道癌のX線学的特徵をさら に詳細に検討するため $\mathrm{A}_{3}$ 食道癌 よりも軽度の深達度が予想され る。すなわち $\mathrm{a}_{1,2}$ が予想される中 間型， $\mathrm{a}_{0}$ が予想される表層型， sm が予想される早期型などと占 居部位, 壁在性, 長さ, X線型,

表 $1 \mathrm{~A}_{3}$ 食道癌のX線学的所見 $(87$ 例） $1965 \sim 1978.8$ 千大 2 外

\begin{tabular}{|c|c|c|c|c|c|c|}
\hline $\begin{array}{c}\text { 強壁 } \\
\text { 度 }\end{array}$ & 狭 & 穿 & 屈 & 膨 & 仙 & 穿 \\
\hline 整 & 窄 & 通 & 曲 & 隆 & 凹 & 孔 \\
\hline 87 & 34 & 72 & 16 & 3 & 3 & 5 \\
$(100 \%)$ & $(39)$ & $(82)$ & & $(25)$ & $(0.5)$ \\
\hline
\end{tabular}




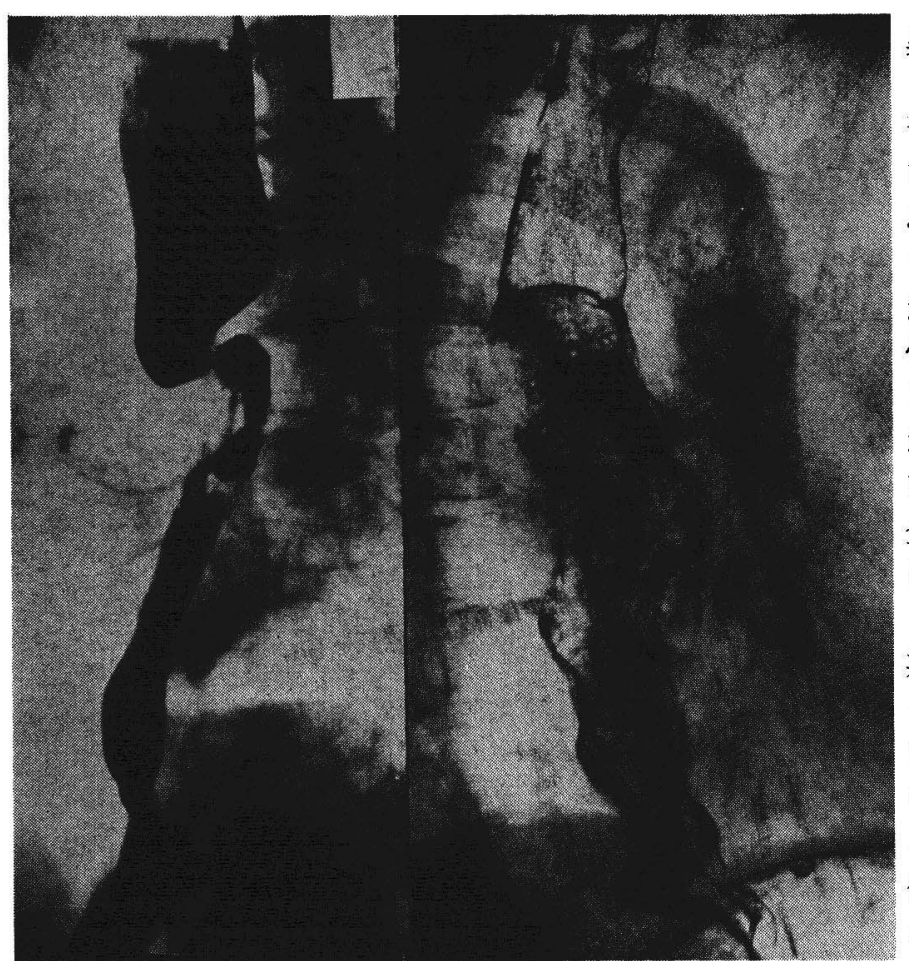

図 $2 \mathrm{c}$ 屈曲像

d 膨隆像

異は認められない(表 2 )。

壁在性との関係では早期型では $1 / 2$ 周にみたないものが $/ 3$ をしめて いて，表層型では $1 / 2$ 周から全周に みたないものが約半数をしめてい て早期，表層型では全周性のもの が非常に少ない。中閒型では全周 性のものが166例中 112 例と約 $2 / 3$ を しめ， $\mathrm{A}_{3}$ になると全周性のもの が87例中81例とほとんどをしめて いる。中間型ことに $\mathrm{A}_{3}$ になると 全周性の壁在性を示すものが非常 に多いということになる(表 3 )。

長さとの関係を検討すると, 早 期型では $6 \mathrm{~cm}$ 〈 0 ものは 1 例もな く全例 $1 \leqq 6 \mathrm{~cm}$ である。表層型で は $9 \mathrm{~cm}\langle 1$ りのはなく $3\langle 1 \leqq 6 \mathrm{~cm}$ のものが最も多い。中間型になる と $3 〈 \mathrm{l} \leqq 6 \mathrm{~cm}$ ののが 166 例中 82 例と約半数をしめ $6\langle 1 \leqq 9 \mathrm{~cm}$ のも の 67 例， $1 \leqq 3 \mathrm{~cm}$ のものは 4 例と 非常に少ない。 $\mathrm{A}_{3}$ になると $1 \leqq 3$

$\mathrm{X}$ 線学的所見, 術前合併療法前後の X線学的所 見, 浸潤藏器などについて検討することにする。 占居部位では $A_{3}$ 食道癌, 中間型 $\left(a_{1,2}\right)$, 表層 型 $\left(\mathrm{a}_{0}\right)$, 早期型 $(\mathrm{sm})$ ともに $\mathrm{I}_{\mathrm{m}}$ が最も多くなって いるがいずれにしても占居部位では特徴的な差

表 2 食道癌の占居部位 (切除282例) 1965 1978. 8 千大 2 外

\begin{tabular}{|c|c|c|c|c|c|}
\hline & & $\mathrm{Ce}_{\mathrm{e}}$ & $I_{u}$ & $\mathrm{I}_{\mathrm{m}}$ & $\mathrm{E}$ \\
\hline $\mathrm{A}_{3}$ & 87 & 5 & 3 & 70 & 9 \\
\hline 中 間 $\left(a_{1,2}\right)$ & 166 & 4 & 18 & 97 & 47 \\
\hline 表 層 $\left(\mathrm{a}_{0}\right)$ & 20 & 1 & 5 & 11 & 3 \\
\hline 早 期 (sm) & 9 & & 2 & 7 & \\
\hline
\end{tabular}

表 3 食道癌の壁在性 (切除282例) 1965 1978.8 千大 2 外

\begin{tabular}{|cc|c|c|c|}
\hline & & $\begin{array}{c}\text { 壁在性 } \\
<1 / 2 \text { 周 }\end{array}$ & $\begin{array}{c}1 / 2 \text { 周 } \\
\text { 性 }<\text { 壁在 }\end{array}$ & 全 周 \\
\hline $\mathrm{A}_{3}$ & 87 & & 6 & 81 \\
\hline 中 間 $\left(\mathrm{a}_{1,2}\right)$ & 166 & 1 & 53 & 112 \\
\hline 表 層 $\left(\mathrm{a}_{0}\right)$ & 20 & 6 & 11 & 3 \\
\hline 早 期 $(\mathrm{sm})$ & 9 & 6 & 2 & 1 \\
\hline
\end{tabular}

表 4 食道澏のX線上の長さ（切除282例） 1965 1978. 8 千大 2 外

\begin{tabular}{|c|c|c|c|c|c|}
\hline & $1 \leqq 3 c m$ & $\begin{array}{c}3<1 \\
\leqq 6\end{array}$ & $\left|\begin{array}{c}6<1 \\
\leqq 9\end{array}\right|$ & $\begin{array}{c}9<1 \\
\leqq 12\end{array}$ & $12<1$ \\
\hline 87 & & 4 & 46 & 32 & 5 \\
\hline 中間 $\left(a_{1,2}\right) 166$ & 4 & 82 & 67 & 13 & \\
\hline 表層（ $\mathrm{a}_{0} ） \quad 20$ & & 15 & 5 & & \\
\hline 早期（sm） 9 & 2 & 7 & & & \\
\hline
\end{tabular}

表 5 食道癌のX線型（切除282例）

1965 1978. 8 千大 2 外

表在型腫瘤型鋸歯型螺施型漏斗型

\begin{tabular}{|l|l|l|l|l|l}
$\mathrm{A}_{3} \quad 87$ & & 2 & 8 & 76 & 1 \\
\hline 中間型 $\left(\mathrm{a}_{1,2}\right)$ & & & 39 & 124 & 3 \\
\hline 166 & & & 7 & 1 & \\
\hline 表層型 $\left(\mathrm{a}_{0}\right) 20$ & 4 & 8 & 7 & \\
\hline 早期型 $(\mathrm{sm}) 9$ & 9 & & & & \\
\hline
\end{tabular}

$\mathrm{cm}$ のものはなく, $6\langle 1 \leqq 9 \mathrm{~cm}$ ものが約半数を しめ $9\langle 1 \leqq 12 \mathrm{~cm} 32$ 例, となっている。このよ5 に長さが増すにつれてその深達の程度も厳しく なる傾向にあるといえる(表 4)。

X線型との関係を検討すると早期型はす心゙て 
日気食会報，31（3），1980

表 6 食道癌の X線学的所見 (切除282例)

1965 1978. 8 千大 2 外

\begin{tabular}{|c|c|c|c|c|c|c|c|c|c|c|}
\hline & $\mid$ & $\begin{array}{l}\text { 軽壁 } \\
\text { 度整 } \\
\text { の整 }\end{array}$ & $\begin{array}{l}\text { 対壁 } \\
\text { 側硬 } \\
\text { の化 }\end{array}$ & 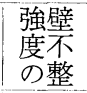 & $\begin{array}{l}\text { 狭 } \\
\text { 窄 }\end{array}$ & $\begin{array}{l}\text { 穿 } \\
\text { 通 }\end{array}$ & 曲 & $\begin{array}{l}\text { 膨 } \\
\text { 隆 }\end{array}$ & 凹 & $\begin{array}{l}\text { 穿 } \\
\text { 孔 }\end{array}$ \\
\hline \multirow{2}{*}{$A_{3} \quad 87$} & & & & 87 & 34 & 72 & 16 & 3 & 3 & \multirow{2}{*}{$\begin{array}{c}5 \\
(0.5)\end{array}$} \\
\hline & & & & $(100 \%)$ & (39) & (82) & \multicolumn{3}{|c|}{ (25) } & \\
\hline$\underset{\left(a_{1,2}\right)}{\text { 中 間 }} 166$ & & & & $\begin{array}{c}166 \\
(100)\end{array}$ & $\begin{array}{r}101 \\
(60)\end{array}$ & & & & & \\
\hline $\begin{array}{l}\text { 表 層 } 20 \\
\left(\mathrm{a}_{0}\right)\end{array}$ & & $\begin{array}{c}20 \\
(100)\end{array}$ & $\begin{array}{c}18 \\
(90)\end{array}$ & & & & & & & \\
\hline $\begin{array}{l}\text { 早 期 } \\
(\mathrm{sm})\end{array}$ & $\begin{array}{c}9 \\
(100)\end{array}$ & & & & & & & & & \\
\hline
\end{tabular}

30例, 残る例は食道壁のみの改善例や改 善所見のない例となっている。 $\mathrm{A}_{3}$ にな ると32例のうち癌巣の消失や癌巣の縮小 と食道壁の改善例はおのおの 1 例， 3 例 と非常に少なく, 食道壁のみの改善, 改 善所見のないものはおのおの19例，9例 で非常に多くなっている。このように $\mathrm{A}_{3}$ における術前合併療法の効果は，中間 型, ことに表層型, 早期型に比較してそ の効果が期待できる例は非常に少ないと いえる。従ってその組織学的効果の期待 できる $\mathrm{Ef}_{3} \mathrm{Ef}_{2}$ 症例も非常に少ないとい うことが推察できるといえる(表 7 )。

表在型である。表層型は腫瘤型 8 例が最も多く, 鋸歯型 7 例, 表在型 4 例, 螺施型 1 例である。 中間型では螺施型が最も多くついで鋸歯型の順 で， $\mathrm{A}_{3}$ になると螺施型が87例中 78 例となって いて圧倒的に多くなっている(表 5 )。

ここで $\mathrm{A}_{3}$ 食道癌の $\mathrm{X}$ 線学的所見をさらに詳 細に検討するため早期, 表層, 中間の各型と比 較すると（表 6 )，早期，表層型では癌巣に一 致する食道壁の変化は非常に軽度であるが，中 間型で治強度の壁不整像と狭窄像がおもな所見 である。 $\mathrm{A}_{3}$ では強度の壁不整像に狭窄, 穿通, 屈曲, 膨隆, 凹凸, 穿孔といったようなきびし い所見が合併しているといら結果となっている (表6)。

現在食道癌の治療成績を向上させる目的で手 術前に放射線療法, 化学療法, 免疫療法などが 単独にまたは合併しておこなわれている。そこ で術前の合併療法を掞こない, かつ合併療法施 行前後のX線学的所見を検討できた例につい て, 検討した。なお, 合併療法を施行後のX線 学的所見は施行 7 日前後で合併療法としては照 射量は2000〜4500 rad, BLMは 60〜180mg, P.S. K.は60〜210gである。術前合併療法前後のX X線 学的所見の指標として, 癌巣の消失, 癌巣の縮 小と食道壁の改善, 食道壁のみの改善, 改善所 見の認められない所見の計 4 所見として, 比較 検討した。早期型では，3例ともに癌巣は消失 し, 表層型では 10 例中, 1 例が癌巣は消失し, 5 例は癌巣の縮小と食道壁の改善所見を示し，4 例は改善所見は認められなかった。中間型では 76例のらち癌巣の縮小と食道壁の改善所見例が
表 7 術前合併療法前後のX線学的所見

(検討121例) 1965 1978.8 千大 2 外

\begin{tabular}{|c|c|c|c|c|}
\hline & $\begin{array}{l}\text { 癌巣の } \\
\text { 消 }\end{array}$ & $\begin{array}{l}\mid \text { 癌巣の縮食と道 } \\
\text { 壁の改善 }\end{array}$ & $\begin{array}{l}\text { 食道壁 } \\
\text { の改善 }\end{array}$ & $\begin{array}{l}\text { 改善所 } \\
\text { 見なし }\end{array}$ \\
\hline 32 & 1 & 3 & 19 & 9 \\
\hline 中間 $\left(\mathrm{a}_{1,2}\right) 7$ & 1 & 30 & 13 & 32 \\
\hline 表層 $\left(a_{0}\right) \quad 10$ & 1 & 5 & & 4 \\
\hline 早期 ( $\mathrm{sm}$ ) 3 & 3 & & & \\
\hline
\end{tabular}

表 $8 \mathrm{~A}_{3}$ 食道癌の占居部位と浸潤藏器 (80例)

\begin{tabular}{|cc|c|c|c|c|c|}
\hline & & 肺 & \multicolumn{2}{|c|}{ 気管 } & \multicolumn{2}{|c|}{ 大動脈横隔膜 } \\
\hline $\mathrm{C}$ & $(5)$ & 1 & 4 & & & \\
\hline $\mathrm{I}_{\mathrm{u}}$ & $(3)$ & 1 & 1 & 1 & & \\
\hline $\mathrm{I}_{\mathrm{m}}$ & $(64)$ & 16 & 5 & 44 & & 1 \\
\hline $\mathrm{E}$ & $(8)$ & & & 5 & 4 & \\
\hline & & 18 & 10 & 50 & 4 & 1 \\
\hline
\end{tabular}

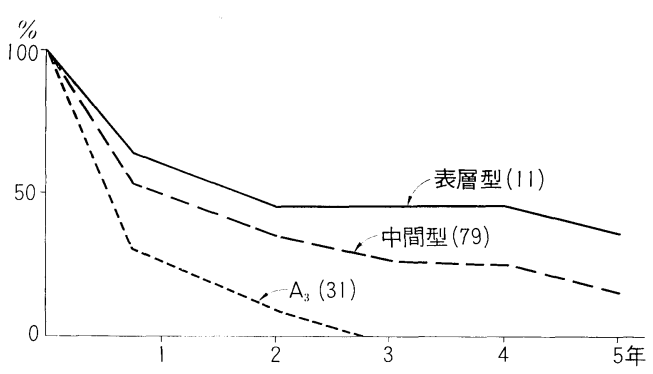

図 3 深達度よりみたX線型と 5 生率 (追求121例) 千大 2 外

つぎに $\mathrm{A}_{3}$ が予想された87例についての手術 所見はどのようなものであったかという問題に 1965 1978. 8 千大 2 外 
ついて検討する。 $\mathrm{A}_{3}$ が予想された 87 例のらち, 7 例は手術時 $\mathrm{A}_{3}$ でなかったため残る 80 例につ いての手術所見を検討する。また $\mathrm{A}_{3}$ と予想し た87例のらち80例 $90 \%$ が $\mathrm{A}_{3}$ と診断できたわけ である。浸潤臓器では大動脈 50 例と最も多く, ついで肺18例，気管11例，横隔膜 4 例，心外膜 1例となっている。これを, さらに癌腫の占居 部位別に検討すると $\mathrm{C}_{\mathrm{e}}$ では気管が最も多く, $\mathrm{I}_{\mathrm{u}}$ てでは肺，気管，大動脈が各 1 例 $\mathrm{I}_{\mathrm{m}}$ では 64 例 のうち大動脈が 44 例と，最も多く，ついで肺 16 例, 気管 5 例となっている。Eでは大動眽 5 例, 横隔膜 4 例となっている(表 8 )。

以上述べてきたような $\mathrm{A}_{3}$ 食道癌を切除した

表 9 食道癌の胸管造影所見（検索25例）

異常所見出現率 $4 / 25(16 \%)$ 千葉大 2 外

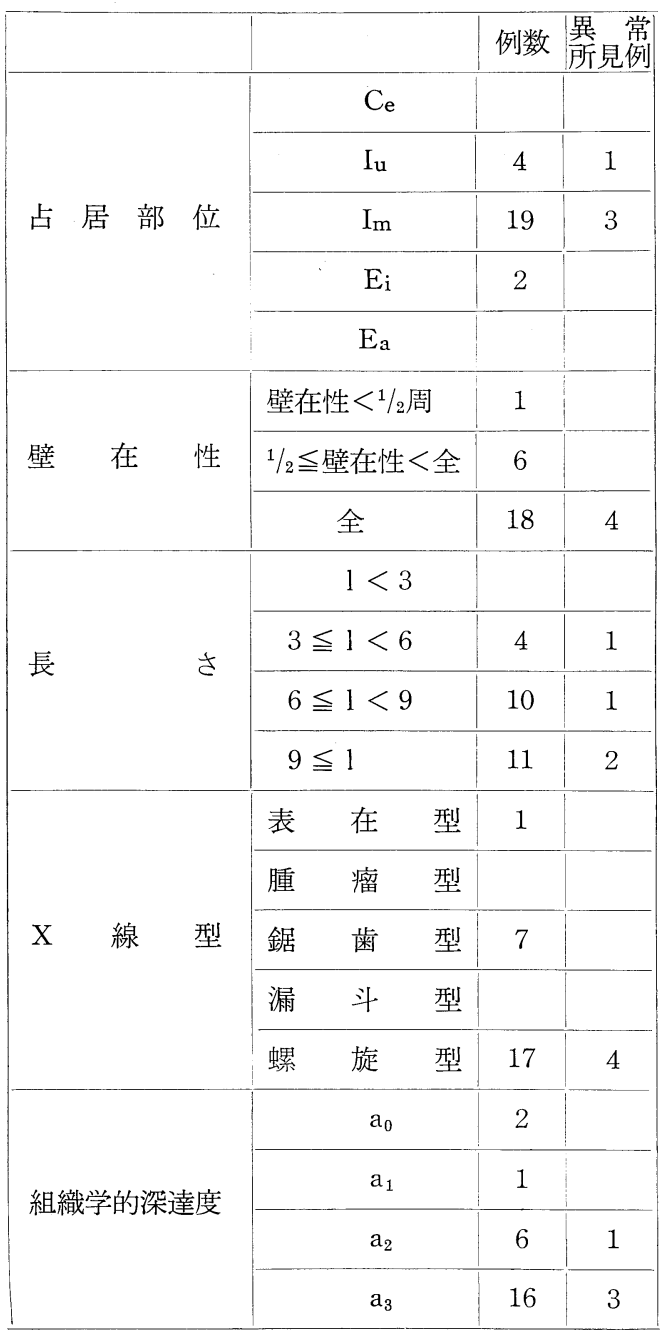

場合，その予後はどのようなものであるかとい 万問題を検討する。 5 生率を追求できる例につ いて検討すると，表層型 $\left(\mathrm{a}_{0}\right)$ の 5 生率は $36 \%$, 中間型 $\left(\mathrm{a}_{1,2}\right)$ の 5 生率は $16 \%$ で， $\mathrm{A}_{3}$ の 5 生率は 最も悪く 5 年生存例はなく全例 3 年以内に死亡 している。また早期型の予後は 5 生率が追求で きないため省略することにする（図 3 ）。以上 $\mathrm{A}_{3}$ 食道癌について， $\mathrm{A}_{3}$ 食道癌よりも深達度の 軽度な中間型 $\left(\mathrm{a}_{1,2}\right)$, 表層型 $\left(\mathrm{a}_{0}\right)$, 早期型 $(\mathrm{sm})$ などに比較して, 占居部位, 壁在性, 長さ, X線 型, X線学的所見, 術前合併療法前後の X線学 的所見, 浸潤藏器, 予後などについて検討した。

\section{結 論}

食道の周囲臟器に癌浸潤を認める $\mathrm{A}_{3}$ 食道癌 について $\mathrm{A}_{3}$ 食道癌よりも深達度の軽度な食道 癌と比較して，X線学的所見，占居部位，壁在 性, 長さ，X線型, 術前合併療法の効果 ${ }^{7)}$, 予後 などについて検討してきたが $\mathrm{A}_{3}$ 食道癌につい ては臨床上診断方法，治療，予後などについて のいくつかの問題点が認められる。 $\mathrm{A}_{3}$ 食道癌 の診断方法としては奇静脈造影法を応用する試 み や胸管造影法を応用する試み2) またX線上 の食道軸の変位をきたす食道癌症例は他藏器に 浸潤しているという秋山らの報告3)もあり，ま た縦隔造影を応用したり，気管の可動性の有無 により， $A_{3}$ 食道癌を診断するといったような いろいろの方法が応用されている。われわれも 食道癌 25 症例に胸管造影時に食道造影をも同時 におこなった(表 9 )。

25例における脑管造影所見で異常所見の認め られたものはわずかに 4 例であり，組織学的に $\mathrm{a}_{3}$ と判明した 16 例のうち 3 例のみに癌浸潤によ る異常所見が認められたのみでしかもその占居 部位は， $\mathrm{I}_{\mathrm{u}}, \mathrm{I}_{\mathrm{m}}$ の症例であった。いずれにして も胸管造影所見, 奇静脈造影所見などからは $\mathrm{A}_{3}$ 食道癌を的確に把握するのは非常に困難であろ ら。われわれは $\mathrm{A}_{3}$ 食道癌の $\mathrm{X}$ 線学的所見とし て食道造影上強度の壁不整像, 穿通, 穿孔, 癌 巣自体の屈曲，膨隆，凹凸像などの所見を把握 して $\mathrm{A}_{3}$ 食道癌を非常に高率に診断してい

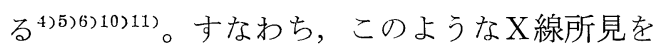
術前に的確に把握すれば術前に $\mathrm{A}_{3}$ 食道癌を非 常に高率に診断できるということになる。 
$\mathrm{A}_{3}$ 食道癌の外科的治療であるが ${ }^{8) 9112)}$ ，浸潤 臓器は前述のように心囊膜, 横隔膜, 肺, 喉頭, 気管,気管支, 大動脈といったようにいろいろの 臟器があるため浸潤藏器により治療方法も当然 ことなってくるといえる。すなわち $\mathrm{A}_{3}$ 食道癌 の外科的治療は前述のいろいろの浸潤臟器を合 併して切除しなければならないのである。しか し，現段階では心囊膜，横隔膜，肺の一部など の場合は積極的に合併切除される傾向となって きたが，気管や大動脈の合併切除となると今後 の残された大きな問題である。また $\mathrm{A}_{3}$ 食道癌 の予後はどらであろらか。 $\mathrm{A}_{3}$ 食道癌以外の食 道癌症例の予後と比較するとたしかによくない のであるが切除しなかった $\mathrm{A}_{3}$ 食道癌よりも予 後はよく，また 5 年生存例も非常に少数ではあ るが認められるよらになってきたことを考える と，手術手技の工夫や，合併療法を駆使して， その治療成績を是非とも向上させたいものであ る。

\section{文献}

1) 山田明義：胸部食道癌に対する奇静脈造影法の 診断的価值について, 千葉医学会誌, $43: 710$, 1967.
2 ）立花孝史 - 他：胸管造影法の検討，外科診療, $12: 862-867,1970$.

3 ）木暮喬, 秋山洋 - 他: 食道癌の手術適応とX線 上の食道軸について，外科，32：673-683, 1970.

4 ) 植松貞夫 ・他: 食道癌の深達度よりみたX線学 的所見, 癌の臨床, 18:365-369, 1972.

5 ）佐藤博, 植松貞夫：食道造影法, 外科, $36: 171$ $-177,1974$

6 ）佐藤博, 植松貞夫 : 食道疾患の X線診断, 外科 治療, 35：162-170，1976

7 ）植松貞夫・他：食道癌における術前合併療法前 後のX線学的所見と組織学的効果との関係, 臨床 放射線，24:451-456，1979.

8 ）磯野可一 - 他：食道癌の進行度と切除適応の問 題, 日消化外会誌, $6: 55,1973$.

9 ）鍋谷欣市 - 他：食道癌の進行度と手術適応の限 界，日消化外会誌，5：345，1972。

10）植松貞夫：消化器疾患診断図譜, 食道編, 佐藤 博監，医歯薬出版，東京，pp. 9-61，1974。

11）植松貞夫・他：切除できなかった食道癌の $X$ 線 学的検討, 臨床放射線, 25:21-26, 1980.

12) 葛西森夫・他：他臟器に浸潤の及んだ食道癌の 外科的治療, 第32回日本胸部外科シンポジウム.

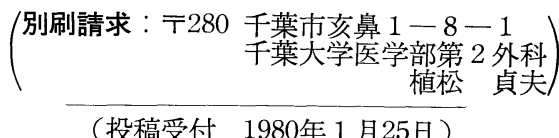

